\title{
Perilaku Cybersex pada Remaja
}

\author{
Nila Anggreiny \\ Program Studi Psikologi, Fakultas Kedokteran, Universitas Andalas \\ nilaanggreiny@gmail.com \\ Septi Mayang Sarry \\ Program Studi Psikologi, Fakultas Kedokteran, Universitas Andalas \\ Septimayangsari.mp2@gmail.com
}

\begin{abstract}
Abstrak
Penelitian ini bertujuan untuk melihat gambaran perilaku cybersex pada remaja. Penelitian ini menggunakan metode kuantitatif deskriptif. Alat ukur dalam penelitian ini adalah adaptasi dari skala Internet Sex Screening Test (ISST) berdasarkan teori Delmonico (1999) dan juga menggunakan kuesioner terbuka. Subjek dalam penelitian ini adalah remaja pengguna cybersex sebanyak 496 orang di Kota Padang. Hasil dari penelitian ini menunjukkan bahwa subjek berada pada kategori beresiko. Hal ini berarti bahwa remaja yang berada dalam kategori beresiko pada dasarnya tidak memiliki masalah seksual, namun jika aktifitas sexual online dilakukan dengan intens, maka remaja tersebut berpotensi menjadi pecandu. Berdasarkan jumlah respon terbanyak, hal mendorong remaja untuk melakukan aktivitas seksual online adalah karna dorongan seksual. Selain itu, jumlah respon terbanyak dalam melakukan aktivitas seksual online adalah membuka situs porno, melihat video porno, membaca cerita porno, dan mengikuti chat sex.
\end{abstract}

Kata Kunci: cybersex., remaja

\section{Pendahuluan}

Perkembangan teknologi tidak bisa kita elakkan lagi terutama yang berhubungan dengan dunia maya. Internet merupakan salah satu media yang perkembangannya sangat cepat. Berdasarkan hasil survei dari Asosiasi Penyelenggara Jasa Internet Indonesia (2016), diketahui pengguna terbanyak berasal dari kalangan dewasa. Namun, jika dibandingkan dengan jumlah kelompok usia masing-masing, maka kalangan usia 25 hingga 34 tahun dan kalangan usia 10 hingga 24 tahun memiliki peminat yang tinggi. Survei Asosiasi Penyelenggara Jasa Internet Indonesia (2016) menunjukkan, 75,8\% masyarakat dari kalangan usia 25 hingga 34 tahun telah menggunakan internet. Jumlah 
tersebut hanya berbeda tipis dari kalangan usia anak-anak dan remaja, yaitu usia 10 hingga 24 tahun, yaitu sebanyak 75,5\% masyarakat dari kalangan usia tersebut telah menggunakan internet. Angka ini mengalahkan kalangan dewasa dengan rentang usia 35 hingga 44 tahun, yaitu 54,7\% dari kalangan usia tersebut yang menggunakan internet.

Internet selain memberikan dampak positif dan juga dampak negatif, yaitu penyalahgunaan pemakaian internet. Para peneliti membagi penyalahgunaan internet ke dalam dua tipe besar, yaitu menyalahgunakan jaringan komputer sebagai target, seperti hacking (atau membobol jaringan komputer) dan cyberterrorism (terror melalui internet), dan menggunakan internet sebagai alat untuk melakukan berbagai tindakan penyimpangan seperti pencurian identitas, pornografi, dan menguntit orang lain. Thio (2010) mengungkapkan, tipe kedua jauh lebih umum terjadi daripada tipe yang pertama. Thio (2010) juga memaparkan tipe kedua tersebut dibagi menjadi tiga kategori berdasarkan tujuan penggunaan internet, yaitu mendapatkan uang secara mudah, mencari seks, dan mengekspresikan kebencian. Diantara kategori tersebut, penggunaan internet untuk mengakses seks mengalami perkembangan yang pesat. Carnes, Delmonico, dan Griffin (2001) mengistilahkan sejumlah perilaku yang berkaitan dengan seks ketika menggunakan komputer tersebut dengan istilah cybersex.

Laier (2012) mengungkapkan bahwa cybersex berkaitan dengan perilaku yang dimotivasi secara seksual di internet melalui aplikasi internet. Senada dengan definisi tersebut, Cooper, Delmonico, Griffin-Shelley, dan Mathy (2004) menyatakan bahwa cybersex sering disebutkan sebagai subkategori dari OSA (Online Sexual Activities) yang berhubungan dengan penggunaan internet untuk terlibat dalam aktivitas yang memuaskan secara seksual. Carnes, Delmonico, dan Griffin (2001) memaparkan bahwa cybersex terdiri atas tiga kategori, di antara kategori cybersex, aktivitas yang paling popular adalah menonton pornografi, yang merupakan media eksplisit seksual yang terutama ditujukan untuk membangkitkan gairah seksual yang melihatnya (Malamuth \& Huppin, 2005). Stack, Wasserman, dan Kern (2004) mengungkapkan bahwa laki-laki enam kali lebih cenderung untuk melihat pornografi daripada wanita, sedangkan wanita 
dilaporkan lebih memilih cybersex dalam konteks hubungan (melalui email atau ruang obrolan) daripada mengakses gambar pornografi.

Banyak faktor yang menyebabkan tingginya minat remaja terhadap aktivitas cybersex. Griffiths (2004) menyatakan bahwa cybersex digemari masyarakat karena faktor anonimitas dan minim hambatan. Selain itu, berbagai faktor lain dapat berpengaruh pada perilaku seksual remaja, seperti faktor sosial ekonomi yang tidak merata, rendahnya pendapatan dan taraf pendidikan, besarnya jumlah keluarga dan rendahnya nilai agama di masyarakat yang bersangkutan (dalam Sarwono, 2015). Berbagai hal dapat mengakibatkan lemahnya kontrol sosial dan runtuhnya fungsi pengontrol dari lembaga atau institusi sosial sehingga memungkinkan remaja untuk bertingkah laku sendiri tanpa adanya kendali, tanpa kontrol, dan menyebabkan ditinggalkannya remaja secara internal tanpa bimbingan (dalam Kartono, 2014). Dampak mengakses pornografi ini bisa menyebabkan remaja menjadi pelaku kekerasan seksual ( Anggreiny, Sarry dan Aziza, 2016). Penelitian ini untuk melihat gambaran perilaku cybersex pada remaja, sehingga bisa memberikan informasi bentuk perilaku yang muncul serta faktor apa saja yang memicu remaja melakukan perilaku cybersex.

\section{Metode Penelitian}

Fokus dari penelitian ini adalah untuk melihat perilaku cybersex pada remaja, sehingga bisa memberikan informasi bentuk perilaku yang muncul serta faktor apa saya yang memicu remaja melakukan perilaku cybersex. Penelitian ini menggunakan metode kuantitatif dengan pendekatan deskriptif. Instrumen pengumpulan data dalam penelitian ini menggunakan kuesioner terbuka untuk mengetahui kondisi bakal calon sampel yang akan diambil. Setelah itu, akan diberikan skala psikologis untuk mengukur variabel penelitian ini yaitu Skala Cybersex. Peneliti kemudian menyusun dan menganalisa data dari skala psikologis yang diberikan dengan metode statistik dengan menggunakan stastistik deskriptif untuk melihat deskripsi secara komputerisasi dengan dibantu program SPSS 21.0. 


\section{Hasil dan Pembahasan}

Berdasarkan data yang diperoleh, subjek penelitian terdiri atas laki-laki dan perempuan, yang berjumlah 496 orang. Masing-masing adalah 472 orang laki-laki dan 24 orang perempuan. Hal ini dapat dilihat dari tabel berikut:

Tabel 1 Identitas Informan Penelitian

\begin{tabular}{ccc}
\hline Jenis Kelamin & Jumlah & Persentase (\%) \\
\hline Laki-laki & 472 & $95 \%$ \\
Perempuan & 24 & $5 \%$ \\
\hline Total & 496 & $100 \%$ \\
\hline
\end{tabular}

\section{Kategori cybersex pada remaja}

Berdasarkan tabel 2, terdapat tiga kategori cybersex pada remaja, yakni sangat beresiko, beresiko beresiko, dan beresiko rendah terhadap perilaku cybersex. Seseorang dapat dikatakan sangat beresiko perilaku cybersex jika mendapatkan skor besar atau sama dengan 17,83. Untuk kategori beresiko, skor yang didapatkan adalah besar atau sama dengan 9,17 namun kuran dari 17,83. Sedangkan beresiko rendah, merupakan kategori seseorang jika mendapatkan skor kecil dari 9,17. Hal ini dapat dilihat dari tabel berikut ini :

Tabel 2. Kategorisasi Cybersex

\begin{tabular}{ccccc}
\hline Kategorisasi & Rumus & Raw Score & Jumlah & Persentase \\
\hline Sangat Beresiko & $(\mathrm{M}+1,0 \mu) \leq \mathrm{X}$ & $\mathrm{X} \geq 17,83$ & 12 & $1,4 \%$ \\
Beresiko & $(\mathrm{M}-1,0 \mu) \leq \mathrm{X}<($ & $9,17 \leq \mathrm{X}<17,83$ & 305 & $65 \%$ \\
\multicolumn{2}{c}{$\mathrm{M}+1,0 \mu)$} & $\mathrm{X}>9,17$ & 152 & $32,4 \%$ \\
\hline Keresiko rendah & $\mathrm{X}<(\mathrm{M}-1,0 \mu)$ & & \\
$\mathrm{M} \quad:$ Mean teoritis & & & \\
$\mu \quad:$ Standar Deviasi &
\end{tabular}

Berdasarkan hasil penelitian, dapat dilihat bahwa di Kota Padang terdapat 12 orang $(2,6 \%)$ remaja yang berada pada kategori sangat beresiko cybersex, 305 orang (65\%) berada pada kategori beresoko, dan 152 orang $(32,4 \%)$ berada pada kategori beresiko rendah. Hal ini menunjukkan bahwa dari 496 remaha di Kota Padang, sebagian besar berada pada kategori beresiko cybersex. 


\section{Gambaran Aktivitas Seksual Online yang pernah dilakukan subjek Penelitian}

Merujuk pada kategori cybersex yang dijelaskan oleh Carnes, Delmonico, dan Griffin (2001) yaitu mengakses pornografi secara online, melakukan real time dengan teman fantasi, dan cybersex melalui multimedia, diuraikan lebih rinci menjadi 13 bentuk perilaku. Hal ini dapat dilihat pada tabel berikut :

Tabel 3 Gambaran aktivitas Seksual Online yang pernah dilakukan Subjek

\begin{tabular}{cccc}
\hline $\begin{array}{c}\text { Kategori } \\
\text { Cybersex }\end{array}$ & Aktivitas Seksual Online & $\begin{array}{c}\text { Jumlah } \\
\text { Respon }\end{array}$ & $\begin{array}{c}\text { Total } \\
\text { Respon }\end{array}$ \\
\hline Mengakses Situs & a.Melihat gambar porno & 419 & 493 \\
Porno secara & b.Menonton video porno & 350 & 2360 \\
Online & c.Membaca komik porno & 495 & 495 \\
d. Membuka situs porno & 142 & 635 \\
e.Membaca cerita porno & 137 & 133 \\
Real time dengan & f.Mengirim foto/video porno secara personal & 115 & 195 \\
Teman Fantasi & g.Mengirim foto/video di grup media sosial & 372 & \\
Menggunakan & b.Memposting foto erotis di akun pribadi & 159 & 104 \\
Software & i.Memposting video porno & 195 & \\
Multimedia & a.Chatting mesum & & \\
\hline Total Seluruh & c.Melakukan video seks & & \\
Respon & Bermain game porno/seks & & \\
\hline
\end{tabular}

Gambaran Hal yang Mendorong Subjek Penelitian untuk Melakukan Aktivitas Seksual Online

Berdasarkan jawaban dari 496 subjek penelitian, terdapat beragam hal yang mendorong subjek penelitian untuk melakukan aktivitas online. Hal ini digambarkan dari tabel berikut ini:

Tabel 4 Hal yang Mendorong Subjek Penelitian Melakukan Aktivitas Seksual Online

\begin{tabular}{ccc}
\hline Hal yang Mendorong & $\begin{array}{l}\text { Jumlah } \\
\text { Respon }\end{array}$ & Total Respon \\
\hline Faktor Internal & & \\
Dorongan nafsu/senang dan puas/ ketagihan & 21 & 242 \\
Penasaran/ ingin tahu & 86 & \\
Bosan/badmood/ iseng & 35 &
\end{tabular}

Faktor Eksternal 


\begin{tabular}{ccc}
$\begin{array}{c}\text { Ajakan dari teman } \\
\text { Melihat konten porno sebelumnya (film,iklan, } \\
\text { gambar) } \\
\text { Tidak mengisi }\end{array}$ & 70 & 118 \\
\hline Total & 48 & 136 \\
\hline
\end{tabular}

Berdasarkan tabel di atas dapat dilihat bahwa hal yang mendorong subjek melakukan aktivitas seksual online dengan respon terbanyak adalah faktor internal yaitu 242 respon (48.79\%), yang meliputi dorongan nafsu, senang, puas, ketagihan, penasaran, dan ketika bosan/badmood/iseng. Selain itu, faktor eksternal seperti ajakan teman, dan melihat konten porno sebelumnya juga menjadi hal yang mendorong subjek untuk melakukan aktivitas seksual online, dengan 118 respon (23.79\%), sementara itu, $136(27.42 \%)$ tidak mengisi.

\section{Kesimpulan}

Dari 492 subjek, sebagian besar subjek berjenis kelamin laki-laki yaitu sebanyak 472 orang dan perempuan sebanyak 24 orang. Sesuai dengan kriteria subjek penelitian, subjek merupakan remaja yang mengakses cybersex. Mengenai kriteria tersebut, akan dibahas sesuai data yang telah didapatkan. Berdasarkan analisis data penelitian, aktivitas cybersex pada subjek dapat dibagi menjadi tiga tingkatan. Tingkatan tersebut adalah low risk (beresiko rendah), at risk (beresiko), dan high risk (sangat beresiko). Berdasarkan hasil analisis deskriptif yang telah dilakukan, didapatkan hasil bahwa sebagian besar subjek berada pada tingkatan beresiko cybersex sebanyak 305 dan selanjutnya berada pada tingkatan beresiko rendah sebanyak 152 orang serta sangat beresiko sebanyak 12 orang. Jadi, pada umumnya, subjek remaja pada penelitian, aktivitas yang dilakukan adalah beresiko cybersex.

Akses internet dilakukan remaja kota padang melalui beberapa tempat. Pada umumnya, subjek melakukannya di warnet, sekolah, dan tempat lainnya yang menyediakan fasilitas wifi. Selanjutnya, subjek juga mengakses internet di rumah, dan di mana saja seperti dari smartphone mereka.

Menurut Carnes, Delmonico, dan Griffin (2001), cybersex terdiri dari tiga kategori, yaitu mengakses situs porno secara online, realtime dengan pasangan 
fantasi, dan menggunakan software multimedia sebagai penunjang aktivitas sex. Berdasarkan hasil penelitian, aktivitas yang dilakukan oleh subjek penelitian mencakup beberapa teori tersebut. Subjek diketahui mengakses situs porno dengan melihat gambar porno, menonton video porno, membaca komik porno, membuka situs porno, membaca cerita porno dan aktivitas lainnya yang dilakukan melalui website/situs porno. Pada kategori cybersex lainnya diikuti dengan aktivitas real time dengan teman fantasi yang meliputi aktivitas chatting mesum, mencari seseorang untuk berhubungan seksual dan melakukan video seks. Kategori aktivitas lainnya yaitu menggunakn software multimedia melalui aktivitas bermain game porno/seks. Berdasarkan penjelasan tersebut, maka subjek telah melakukan beberapa perilaku seksual online (cybersex) berdasarkan teori Delmonico dan Miller (2008).

\section{DAFTAR PUSTAKA}

Azwar, S. (2013). Penyusunan skala psikologi. Yogyakarta: Pustaka Belajar.

Cooper, A., Delmonico, D.L., Griffin-Shelley, E., dan Mathy, R.M. (2004). Online sexual activity: An examination of potentially problematic behavior. Sexual Addiction \& Compulsivity, 11, 129-134.

Cooper, A., Mansson, S.A., Daneback, K., Tikkanen, R.,\& Ross, M.(2003). Predicting the future of internet sex: Online sexual activities in Sweden. Sexual and Relationship Therapi, 18 (3), 277-291.

Daneback, K., Cooper, A., \& Mansson, S.A. (2005). An internet study of cybersex participants. Archives of Sexual Behavior, 34 (3), 321-328.

Delmonico, D.L., \& Griffin, E.J. (2008). Online sex offending. Dalam Laws, D.R., \& O’Donohue, W.T. (2008). Sexual Deviance: Theory, Assesment, and Treatment(459-485). New York: The Guildford Press.

Delmonico, D.L., \& Miller, J.A. (2003). The internet sex screening test: A comparison of sexual compulsives versus non-sexual compulsives. Sexual and Relationship Therapy, 18 (3), 261-276.

Dewangga, L.K., \& Rahayu, M.S. (2015). Hubungan antara kontrol diri dengan cybersexual addiction pada siswa SMP di Orange-net Bandung. Prosiding Psikologi Unisba, 2, 137-143. 
Griffiths, M. (2004). Sex addiction on the internet. Janus Head, 7 (1), 188-217.

Griffiths, M.D. (2012). Internet sex addiction: A review of empirical research. Addiction Research and Theory, 20, 111-124.

Hirschi, T. (1969). Causes of delinquency. Berkeley, CA: University of California Press.

Janowitz, Morris. (1975). Sociologycal theory and social control. American Journal of Sociology, 81(1), 83.

Karapetsas, A.V., \& Fotis, A.J. (2013). The phenomenon of cybersex addiction: its reason, diagnosis, and how to fight it off. Encephalos, 50, 104-108.

Krueger, R.B., Weiss, S.L., Kaplan, M. S., Braunstein, J., \& Wiener, E. (2013). The impact of internet pornography use and cybersexual behavior on child custody and visitation. Journal of Child Custody, 10 (1), 68-98.

Anggreiny, A., Sarry, S.M \& Aziza, A., (2016)., Dinamika Psikologi pada Remaja Pelaku Kekerasan Seksual. Jurnal Psikologia, 11(3), 112-122

Papalia, D.E., Olds, S.W., \& Feldman, R.D. (2003). Human development (9 $9^{\text {th }}$ Ed.). New York: McGraw-Hill.

Santrock, J.W. (2008). Adolescence (twelfth edition). New York: McGrawHill.Sari, N.N., \& Purba, R.M. (2012). Gambaran perilaku cybersex pada remaja pelaku cybersex di kota medan. Psikologia-online, 7 (2), 62-73.

Sugiyono. (2013). Metode penelitian kuantitatif, kualitatif, dan kombinasi (mixed methods) (cetakan ke-tiga). Bandung: Alfabeta.

Wery, A., \& Billieux, J. (2015). Problematic cybersex: conseptualization, assessment, and treatment. Addictive Behaviors. http://dx.doi.org/10.1016/j.addbeh.2015.11.007

Wiatrowski, M.D. (1978). Social control theory and delinquency. Portland: Portland State University.

Young, K.S. (2008). Internet sex addiction: risk factors, stages of development, and treatment. American Behavioral Scientist, 52 (1), 21-37 